\title{
Evaluation of groundwater quality based on radiological and hydrochemical data from two uraniferous regions of Western Iberia: Nisa (Portugal) and Ciudad Rodrigo (Spain)
}

\author{
A. J. S. C. Pereira • M. D. Pereira $\cdot$ L. J. P. F. Neves • \\ J. M. M. Azevedo $\cdot$ A. B. A. Campos
}

Received: 21 November 2013/ Accepted: 29 June 2014/Published online: 9 August 2014

(C) Springer-Verlag Berlin Heidelberg 2014

\begin{abstract}
The regions of Nisa (Portugal) and Ciudad Rodrigo (Spain) are characterized by a high radiation background due to the presence of uranium-enriched rocks. To evaluate the water quality of the shallow aquifers and the relationship between radiological and non-radiological variables, a set of 41 samples was collected (mainly from springs) and analyzed for the radioisotopes ${ }^{238} \mathrm{U},{ }^{234} \mathrm{U}$, ${ }^{226} \mathrm{Ra}$ and ${ }^{222} \mathrm{Rn}$ as well as for some major and minor cations. The results obtained for the cationic composition in both areas show some differences in terms of geological bedrock, with higher mineralization and hardness in the Spanish samples (Ca-Mg facies); the Nisa samples are included in the $\mathrm{Na}-\mathrm{K}$ facies. The indicative effective dose was calculated for several age groups. On average, the effective dose is higher in Nisa due to the activity in ${ }^{226} \mathrm{Ra}$, and $25 \%$ of the total dataset puts ${ }^{222} \mathrm{Rn}$ above the recommended acceptable maximum. Despite the low-scale ancient uranium exploitation works in the Nisa area in comparison to those carried out on the Spanish side, the higher risk calculated in the Portuguese region reinforces the importance of taking into account the natural background when the goal is to control the exposure of the population to ionizing radiation.
\end{abstract}

A. J. S. C. Pereira $(\varangle)$ · L. J. P. F. Neves · A. B. A. Campos IMAR, Departamento de Ciências da Terra, Universidade de Coimbra, Coimbra, Portugal

e-mail: apereira@dct.uc.pt

M. D. Pereira

Departamento de Geologia, Universidad de Salamanca, Salamanca, Spain

J. M. M. Azevedo

Centro de Geofísica, Departamento de Ciências da Terra,

Universidade de Coimbra, Coimbra, Portugal
Keywords Groundwater - Quality - Major and trace elements $\cdot$ Radioisotopes $\cdot \mathrm{U} \cdot$ Iberia

\section{Introduction}

Since the middle of the twentieth century, the existence of a geological setting is well known in Central Iberia that favors the presence of rocks with a uranium content well above the crustal average, very often with high local enrichment, able to yield the formation of ores. These characteristics led to the classification of the region as a metallogenic province (Dias and Andrade 1970) extending from the central part of the Portuguese territory to the nearby Spanish territory.

The radioactive decay of the isotopes of the uranium chain is expected to increase the radiation background that reaches the human population living in these areas, through different pathways: exposure to gamma radiation produced by the geological materials, as well as ingestion of radioisotopes, through water and food consumption, or inhalation of particles and radioactive gas, as radon.

In Iberia, these areas with a high natural radiation background have not been extensively studied in terms of their radiological characteristics; consequently, the impact of the radiation on the health of the population is not wellknown, excluding that of radon (Pereira and Neves 2012; Torres et al. 1992). On the other hand, the estimation of the radiological risk associated with the exploitation of the uranium ores has received far more attention (e.g., Pereira et al. 2004a, b; Carvalho et al. 2009). In the latter situation, because the studies were usually carried out after the exploitation works ended, it is not easy to trace with precision the influence of the mining works in the surrounding environment due to the present lack of knowledge 
regarding the environmental background in the preexploitation phase. This fault should be avoided if the mining activity in this region restarts in the future.

The regions of Nisa (Portugal) and Ciudad Rodrigo (Spain) are located in the metallogenic uranium province and several uranium ores were discovered through prospecting works carried out in the twentieth century (Fig. 1). On the Spanish side, some of the ores have been subjected to large-scale exploitation works in the past, but this exploitation has come to a halt since the late 1980s (the best example is the well-known Mina Fé; Arribas et al. 1983). Despite the volume of ores available in the Portuguese area (nowadays the estimated resources are around 4,100 tons), only small-scale exploitation works have been carried out to pursue resource evaluation (Campos 2002).Uranium mining is planned to be taken up again next year in Spain (Berkeley Resources 2013), while in Portugal the future situation is currently uncertain.

The main goal of the present study is to evaluate the risk of exposure of the population to the ionizing radiations associated with one of the possible pathways of uranium radioactive decay, namely the consumption of groundwater collected in the shallow aquifers that occur in the areas of Nisa and Ciudad Rodrigo (ingestion path). Complementary chemical data were acquired in the same sample set, so as to assess the water quality for human consumption as well as the relationship between radiological and non-radiological properties of groundwater. The results of this study may be helpful in diminishing the impacts on groundwater in case uranium mining activities in these two regions are resumed in the near future.

\section{Geological setting}

The main hosts of the uranium mineralization in the study areas are the schists and graywackes included in the "Schist and Greywacke Complex" of Precambrian-Cambrian age (SGC, Pereira and Alonso 2000, Fig. 1). In addition to these lithologies, organic-rich facies (black shales) are also present, as well as siltstones, limestones that have undergone green schist facies metamorphism (Arribas et al. 1983), micro-conglomerates and phosphorites (Arribas et al. 1983; Campos 2002).

On the southeastern side of the Nisa region, a synclinorium of Paleozoic rocks outcrop, with age variable from the Ordovician to the Middle Devonian, which are composed of quartzites, coarse sandstones and slates. These rocks were intruded during the Hercynian orogeny by acid magmatism of granitic composition, with dominance of coarse to very coarse-grained porphyritic biotite granites, late to post-tectonic. These magmas imposed a thermal aureole in the nearby metasedimentary rocks up to an extension of $2 \mathrm{~km}$. In the Nisa region a pre-Hercynian episode of acid magmatism can also be seen, through the intrusion of orthogneisses with NW-SE foliation.

The igneous and metasedimentary rocks are locally overlaid by terrestrial Tertiary sediments (Lower Oligocene to Upper Eocene in age) composed of conglomerates, arkoses, siltstones and mudstones, and cut by several fault systems, with the $\mathrm{N} 30^{\circ} \mathrm{E}, \mathrm{N} 60^{\circ} \mathrm{E}, \mathrm{N} 60^{\circ} \mathrm{W}$ and $\mathrm{N} 30^{\circ} \mathrm{W}$ systems being dominant in both areas (Arribas et al. 1983, Campos 2002). Quartz, granitic and quartz ferruginous breccia as well as fine-grained granite were identified as fault-filling materials.

The occurrence of uranium-enriched rocks was discovered in the Nisa region in the 1950s and in the Ciudad Rodrigo area in the 1960s. As previously stated, most of them are hosted in the SGC; some of them are spatially related to the granite intrusions (enclosed in its metamorphic aureole), but others are not, and this is often the case in the Spanish region (Arribas 1985 and references therein). The main uranium ores discovered in the two regions lay in the metasedimentary rocks. The Fé Mine (Spain, Fig. 1) was exploited until the end of the 1980s (estimated resources of around 15,000 tons) and is spatially not related with granites. The Maria Dias ore deposit, in the Nisa region (Portugal), outcrops in the metamorphic aureole of the Hercynian porphyritic biotite granite (estimated resources of 4,100 tons; Fig. 1). This last uranium ore extends to the west of Nisa village (with a total area of around $3.5 \mathrm{~km}^{2}$, more or less a rectangle with the length along the $\mathrm{N} 80^{\circ} \mathrm{W}$ direction). This uranium deposit is, so far, the richest that has ever been discovered in Portuguese territory (Dias and Andrade 1970; Dias et al. 1990; Campos 2002; Neiva and Dias 2010), but was never subjected to commercial exploitation. On the Portuguese side, minor uranium ores also occur in porphyritic granite in faultfilling materials with strike close to N-S (Campos 2002).

The uranium minerals are irregularly disseminated, namely in free spaces of brecciated faults, foliation planes, joints and micro-fissures. The uranium minerals observed in the Nisa region are pitchblende (scarce), phosphuranylite, saleeite, autunite-uranocircite, torbernite and sabugalite (Dias and Andrade 1970; Neiva and Dias 2010). Pitchblende, black oxides, coracite, gummite, uranotile, autunite, torbernite and uranopilite (Arribas et al. 1983) can be observed on the Spanish side.

The genesis of the uranium mineralization has been a controversial subject in the past (e.g., Arribas 1985; Neiva and Dias 2010). Several models have been proposed for the uranium mineralization in the studied areas, based on currently available data: (a) tectonic-hydrothermal activity, by Arribas (1985) and Martin Izard et al. 2002); and (b) weathering and erosion during Pliocene peneplanation (Dias and Andrade 1970). In the former model, the deposition of uranium minerals was explained by a tertiary 
Fig. 1 Location of the areas in study (I) and simplified geological maps of the Nisa region (II), located in the Portuguese side of the border, and west of the Ciudad Rodrigo region (III), located in the Spanish side; the locations of the groundwater samples are projected on both maps. The caption refers to both maps and geographical coordinates in meters
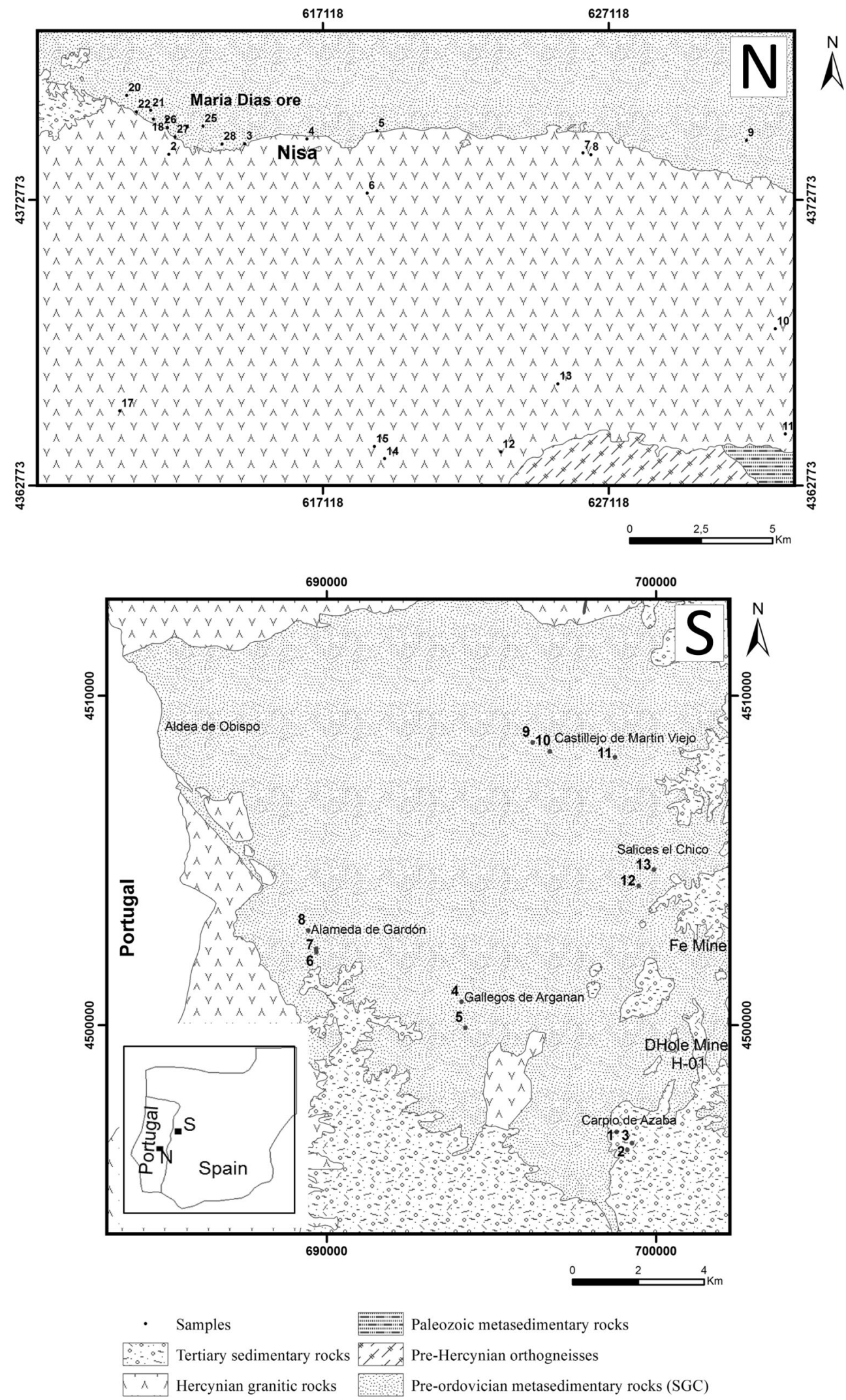
event that affected metasediments and granites alike with remobilization of the uranium initially existent in primary minerals in both geological units (in the first lithology, the mineralization occurs in organic-rich layers with uranium content sometimes as high as $200 \mathrm{mg} / \mathrm{kg}$ - unpublished data from the authors). The latter model suggests that uranium was transported in solution by groundwater and later deposited as uranium minerals due to water-rock interaction phenomena.

\section{Methods and techniques}

During springtime (May), a total of 30 groundwater samples were collected from springs for analysis of major $(\mathrm{Na}$, $\mathrm{Mg}$, $\mathrm{Ca}$ and silica), secondary ( $\mathrm{K}$ and $\mathrm{Fe}$ ) and trace elements ( $\mathrm{Al}, \mathrm{As}, \mathrm{Ba}, \mathrm{Mn}, \mathrm{Ni}$ and $\mathrm{Zn}$ ) (according to the classification by Davis and DeWiest 1967), as well as radioactive isotopes ${ }^{238} \mathrm{U},{ }^{234} \mathrm{U},{ }^{226} \mathrm{Ra}$ and ${ }^{222} \mathrm{Rn}$ (Fig. 1). Major anions were not determined due to sampling and laboratory difficulties. Electrical conductivity (EC) and $\mathrm{pH}$ were included in the field measurements. The sample set includes 12 additional samples, collected in a more restricted area that roughly match the outcrop of the locally designated Maria Dias uranium ore, in the Nisa region (Fig. 1). This last sample set was analyzed only for the isotopes ${ }^{238} \mathrm{U},{ }^{234} \mathrm{U}$ and ${ }^{226} \mathrm{Ra}$. This subset was mainly collected from springs, but also from dug-wells and boreholes of a few dozen meters in depth. A total of 13 samples were obtained on the Spanish side of the border: 3 of them were located in the Tertiary sedimentary cover, while the others were in the pre-Ordovician metasediments of the SGC (Fig. 1). In the Portuguese territory, 2 samples were collected in this last geological unit and 16 others in the porphyritic granite. All the springs are associated with shallow and mostly unconfined aquifers.

The quantification of major and trace elements in the water samples was made using an Ultima 2 Jobin Yvon optical emission plasma spectrometer in the Chemical Analysis Laboratory at the University of Salamanca. $\mathrm{HNO}_{3}$ $0.5 \%$ was added to the samples before the analysis was conducted. Isotopic analysis was performed by liquid scintillation techniques using an ultralow-level spectrometer Quantulus 1220, from Perkin-Elmer, available in the Laboratory of Natural Radioactivity at the University of Coimbra. To measure $\mathrm{U}_{\text {natural }}$ and ${ }^{226} \mathrm{Ra}$, the samples were previously acidified with $\mathrm{HNO}_{3}$ down to a $\mathrm{pH}$ of about 2 and filtered to remove the suspended solid particles. For radon analysis, a 10-ml aliquot of each sample was carefully taken with a syringe so as to avoid loss of gas and immediately injected in a glass vial containing an immiscible scintillation cocktail.

${ }^{226} \mathrm{Ra}$ was measured by an indirect method using ${ }^{222} \mathrm{Rn}$ as a tracer after isotopic equilibrium was reached, following the procedure described in Forte et al. (2002, 2007). A 500-ml aliquot was pre-concentrated by slow evaporation in a proportion of approximately $1: 10$ in the temperature-controlled hotplate. Besides pre-concentrating the sample, this procedure also guarantees radon removal. The uranium isotopes were previously extracted with a mixture of a scintillation cocktail and bis-(2-ethylhexyl) phosphate in accordance with Salonen (1993) and Salonen and Hukkanen (1999). The PSA and the best counting time were previously evaluated for each sample (which was found to vary, in the last case, between 60 and $600 \mathrm{~min}$ ).

The detection limits for the activity of uranium isotopes are $1.5 \mathrm{mBq} \mathrm{L}^{-1}\left(0.15 \mu \mathrm{g} \mathrm{L}^{-1}\right.$, for $\left.\mathrm{U}_{\text {natural }}\right), 0.01 \mathrm{~Bq} \mathrm{~L}^{-1}$ for ${ }^{226} \mathrm{Ra}$ and $1 \mathrm{~Bq} \mathrm{~L}^{-1}$ for radon. In every case, the analytical errors were under $15 \%$ of the measured value ( $\mathrm{p}=095 \%)$.

Following the approach of Desideri et al. (2007) described in Gonçalves and Pereira (2007), the radiological risk for different members of the population can be evaluated through estimation of the effective dose from exposure to ionizing radiation. Radon gas was not taken into account in any calculations, as established in the protocol that regulates this type of analysis.

\section{Results and discussion}

The results of the physical and chemical analysis as well as the calculated statistical parameters are presented in Table 1. All the $\mathrm{pH}$ values point to the presence of neutral or slightly acid waters. The EC and hardness values, with mean values of $419 \mu \mathrm{S} \mathrm{cm}^{-1}$ and $112.54 \mathrm{mg} \mathrm{L}^{-1}$, respectively, reflect a low to average level of groundwater mineralization.

Overall, the analyzed parameters show high variability in most cases, considering the high standard deviations, coefficients of variation and the mean and median relative differences. The EC and hardness, for instance, have a coefficient of variation of 0.73 and 1.10 and median of 346 $\mu \mathrm{S} \mathrm{cm} \mathrm{cm}^{-1}$ and $77.67 \mathrm{mg} \mathrm{L}^{-1}$, respectively. Silica ranges from 3.44 to $12.61 \mathrm{mg} \mathrm{L}^{-1}$, with a coefficient of variation of 0.32 and median of $6.1 \mathrm{mg} \mathrm{L}^{-1}$. The highest variability was detected for trace elements, with coefficients of variation often higher than $100 \%$; Mn, Ni and Fe showed the highest coefficients.

The analytical data of ${ }^{238} \mathrm{U},{ }^{234} \mathrm{U}, \mathrm{U}_{\text {natural }},{ }^{226} \mathrm{Ra}$ and ${ }^{222} \mathrm{Rn}$ as well as the ${ }^{234} \mathrm{U} /{ }^{238} \mathrm{U}$ ratio in the groundwater samples collected in the studied areas are given in Table 2. The histograms of the distributions for $\mathrm{U}_{\text {natural }},{ }^{226} \mathrm{Ra}$ and ${ }^{222} \mathrm{Rn}$ are plotted in Fig. 2.

All the variables display high variability. The histograms show an approximation to a lognormal distribution (for instance, $\mathrm{U}_{\text {natural }}$ and ${ }^{226} \mathrm{Ra}$ ) or, as in the case of ${ }^{222} \mathrm{Rn}$, 


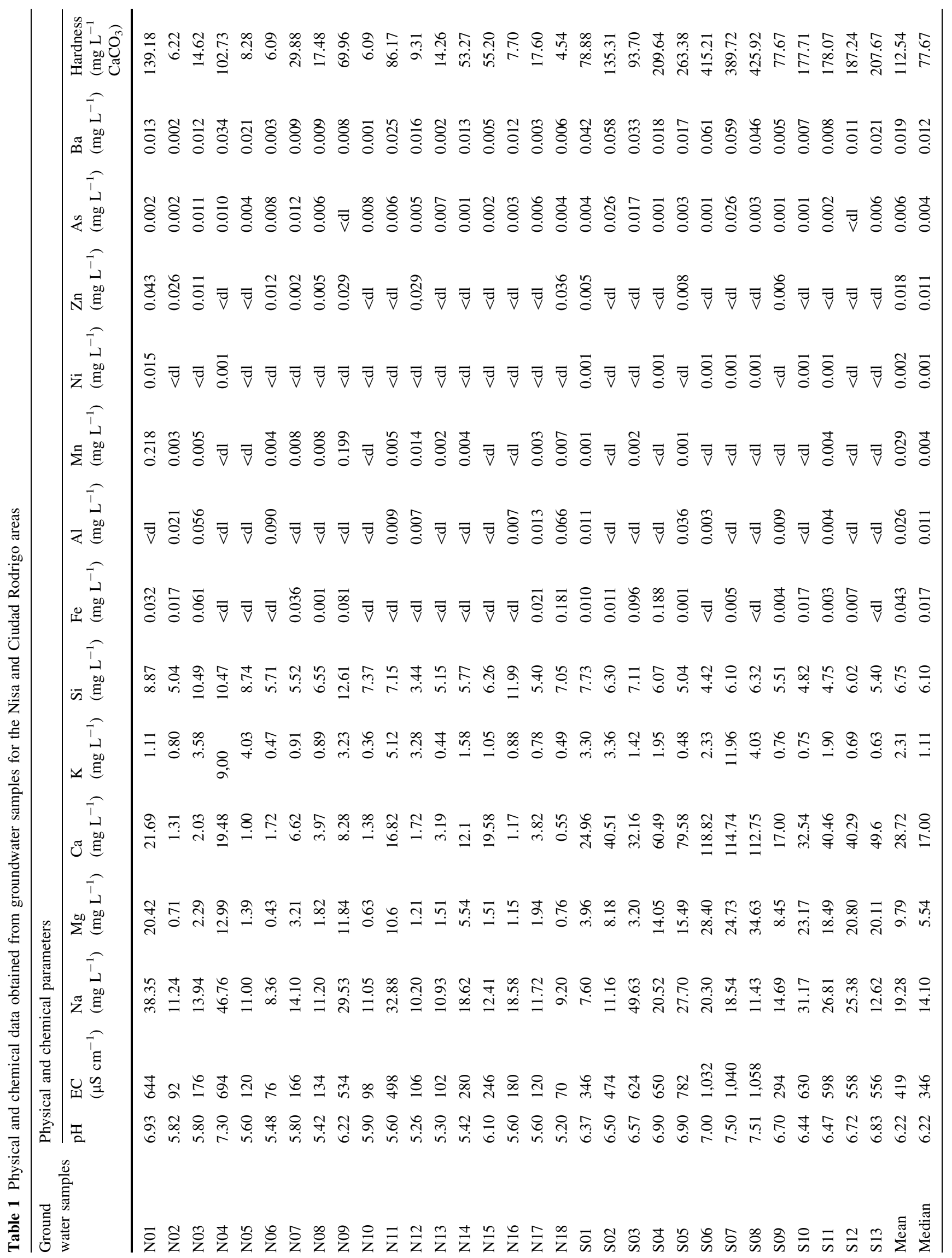




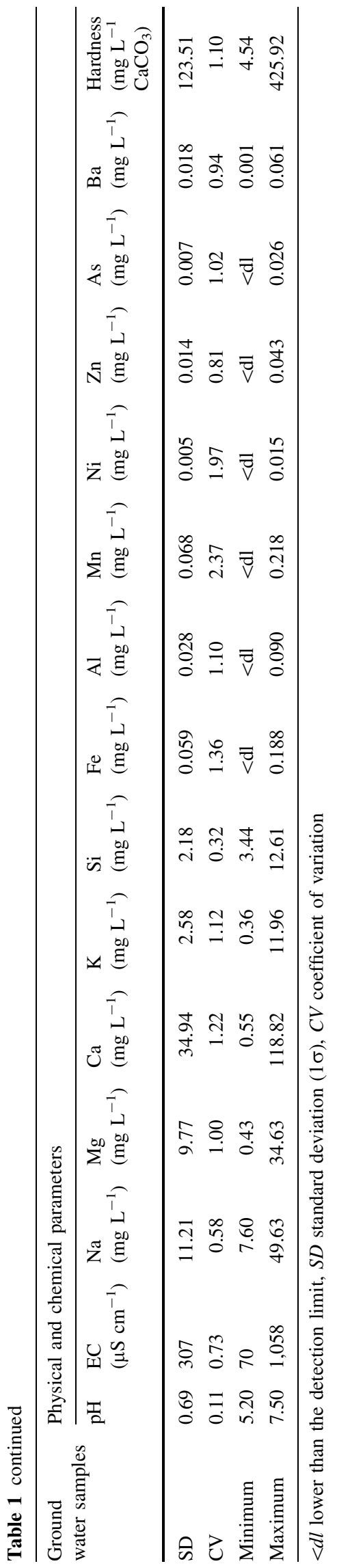

a splitting of the data into two different populations (bimodal distribution). These results were expected given the variability of the geological bedrock in the studied areas, as they are seen to comprise igneous, metasedimentary and sedimentary rocks as well as locally occurring uranium-enriched rocks. Pereira et al. (2010) and Pereira and Neves (2012), referred to a similar pattern in other studies conducted in similar geological settings.

The data obtained from the water samples, from which only radiological properties were measured (N19 to N28), is shown in the same table. The values obtained for this set range within the same interval of variation of the aforementioned set. The former includes water points of different typology (dug-wells and water-holes) as opposed to the previous samples which refer only to springs. However, the analytical results do not differ significantly between the two sets and therefore it can be assumed that all the water points belong to a single population.

The statistics calculated from the obtained analytical results are also plotted in Table 2. With the exception of ${ }^{222} \mathrm{Rn}$, all other radiological parameters have their lowest value under the detection limit of the technique used. The ${ }^{238} \mathrm{U}$ and ${ }^{234} \mathrm{U}$ isotopes range to a maximum of $0.679 \mathrm{~Bq} \mathrm{~L}^{-1}$ and $0.680 \mathrm{~Bq} \mathrm{~L}^{-1}$, respectively. The mean for the same isotopes was 0.087 and $0.094 \mathrm{~Bq} \mathrm{~L}^{-1}$, the median 0.043 and $0.044 \mathrm{~Bq} \mathrm{~L}^{-1}$ and the maximum concentration of $\mathrm{U}_{\text {natural }}$ was $55 \mu \mathrm{g} \mathrm{L}^{-1}$. The mean and median of the isotopic ratio ${ }^{234} \mathrm{U} /{ }^{234} \mathrm{U}$ is higher than one, which indicates a slight enrichment in the light isotope, as is customary in natural waters ( $̊$ kerblom 1994).

The highest activity measured for the ${ }^{226} \mathrm{Ra}$ isotope was $0.234 \mathrm{~Bq} \mathrm{~L}^{-1}$; the mean and the median were 0.027 and $0.016 \mathrm{~Bq} \mathrm{~L}^{-1}$, respectively. Radon gas activity displays a high range of variation, from $1.40 \mathrm{~Bq} \mathrm{~L}^{-1}$ as its lower limit up to $3,856 \mathrm{~Bq} \mathrm{~L}^{-1}$ as its maximum. The calculated mean was $694 \mathrm{~Bq} \mathrm{~L}^{-1}$ and the median $344 \mathrm{~Bq} \mathrm{~L}^{-1}$.

Some of the sampled water points are used for human consumption, namely samples N04, N07, N08, N10, N16, S04 and S05. Thus, it is important to assess the radiological risk of using groundwater collected in aquifers belonging to the studied regions. The World Health Organization sets a maximum acceptable concentration (MAC) for uranium of $30 \mu \mathrm{g} \mathrm{L}^{-1}$ (WHO 2011) and the European Union recommends a maximum of $1,000 \mathrm{~Bq} \mathrm{~L}^{-1}$ for radon gas (EU 2001). By applying these limits to the results obtained from the present study, it can be concluded that in two of the samples (N17 and S05) the concentration does not fall within the acceptable concentration range for uranium, while $25 \%$ of the samples are above the recommended action level of radon.

The statistical data associated with the calculated effective dose from exposure to ionizing radiation measured from the dataset are given in Table 3 . The mean 
Table 2 Radiological data obtained from groundwater collected in springs, wells (*) and boreholes $(* *)$, from granites (A), metasediments of the SGC (B) and Tertiary sediments of Nisa $(\mathrm{N})$ and Ciudad Rodrigo regions (S) $<d l$ lower than the detection limit, $n d$ not determined, $S D$ standard deviation, $C V$ coefficient of variation

\begin{tabular}{|c|c|c|c|c|c|c|c|}
\hline Sample & Lithology & $\begin{array}{l}\left.{ }^{238} \mathrm{U}^{-1}\right) \\
\left(\mathrm{Bq} \mathrm{L}^{-1}\right)\end{array}$ & $\begin{array}{l}\left.{ }^{234} \mathrm{U}^{-1}\right) \\
\left(\mathrm{Bq} \mathrm{L}^{-1}\right)\end{array}$ & $\begin{array}{l}\mathrm{U}_{\text {natural }} \\
\left(\mu \mathrm{g} \mathrm{L}^{-1}\right)\end{array}$ & ${ }^{234} \mathrm{U} /{ }^{238} \mathrm{U}$ & $\begin{array}{l}{ }^{226} \mathrm{Ra} \\
\left(\mathrm{Bq} \mathrm{L}^{-1}\right)\end{array}$ & $\begin{array}{l}{ }^{222} \mathrm{Rn} \\
\left(\mathrm{Bq} \mathrm{L}{ }^{-1}\right)\end{array}$ \\
\hline N01 & B & 0.005 & 0.004 & 0.4 & 0.80 & 0.002 & 167 \\
\hline N02 & A & 0.010 & 0.010 & 0.8 & 1.00 & 0.013 & 513 \\
\hline N03 & A & 0.015 & 0.012 & 1.2 & 0.80 & 0.014 & 860 \\
\hline N04 & A & 0.112 & 0,134 & 9.1 & 1.20 & 0.034 & 17 \\
\hline N05 & A & 0.216 & 0.272 & 17.5 & 1.26 & 0.234 & 3,856 \\
\hline N06 & A & 0.039 & 0.040 & 3.2 & 1.03 & 0.039 & 1,889 \\
\hline N07 & A & 0.089 & 0.090 & 7.2 & 1.01 & 0.054 & 1,641 \\
\hline N08 & A & 0.031 & 0.036 & 2.5 & 1.16 & 0.017 & 269 \\
\hline N09 & B & $<\mathrm{dl}$ & $<\mathrm{dl}$ & $<\mathrm{dl}$ & $<\mathrm{dl}$ & $<\mathrm{dl}$ & 43 \\
\hline N10 & A & 0.043 & 0.057 & 3.5 & 1.33 & 0.001 & 138 \\
\hline N11 & A & 0.072 & 0.075 & 5.8 & 1.04 & 0.046 & 872 \\
\hline N12 & A & 0.008 & 0.007 & 0.6 & 0.88 & 0.084 & 1,988 \\
\hline N13 & A & 0.039 & 0.040 & 3.2 & 1.03 & 0.030 & 551 \\
\hline N14 & A & 0.007 & 0.007 & 0.6 & 1.00 & 0.030 & 112 \\
\hline N15 & A & 0.013 & 0.015 & 1.1 & 1.15 & 0.001 & 65 \\
\hline N16 & A & 0.046 & 0.049 & 3.7 & 1.07 & 0.001 & 80 \\
\hline N17 & A & 0.679 & 0.680 & 55.0 & 1.00 & 0.038 & 1,325 \\
\hline N18 & A & 0.038 & 0.043 & 3.1 & 1.13 & 0.002 & 2,426 \\
\hline $\mathrm{N} 19^{(*)}$ & B & 0.037 & 0.043 & 3.0 & 1.16 & 0.043 & nd \\
\hline $\mathrm{N} 20^{(* *)}$ & B & 0.042 & 0.038 & 3.4 & 0.90 & 0.018 & nd \\
\hline N21 & B & 0.015 & 0.016 & 1.2 & 1.05 & $<\mathrm{dl}$ & nd \\
\hline $\mathrm{N} 22^{(*)}$ & B & 0.128 & 0.090 & 10.3 & 0.71 & 0.036 & nd \\
\hline $\mathrm{N} 23^{(* *)}$ & B & 0.081 & 0.086 & 6.6 & 1.06 & 0.069 & nd \\
\hline $\mathrm{N} 24^{(* *)}$ & B & 0.051 & 0.044 & 4.1 & 0.86 & 0.028 & nd \\
\hline $\mathrm{N} 25^{(*)}$ & B & 0.030 & 0.031 & 2.5 & 1.01 & 0.039 & nd \\
\hline $\mathrm{N} 26^{(*)}$ & B & 0.267 & 0.317 & 21.6 & 1.19 & 0.040 & nd \\
\hline $\mathrm{N} 27^{(* *)}$ & B & 0.267 & 0.217 & 21.6 & 0.81 & 0.048 & nd \\
\hline N28 & B & $<\mathrm{dl}$ & $<\mathrm{dl}$ & $<\mathrm{dl}$ & nd & 0.007 & nd \\
\hline S01 & $\mathrm{C}$ & $<\mathrm{dl}$ & $<\mathrm{dl}$ & $<\mathrm{dl}$ & nd & 0.002 & 1.4 \\
\hline $\mathrm{S} 02$ & $\mathrm{C}$ & 0.055 & 0.060 & 4.4 & 1.11 & 0.001 & 26 \\
\hline S03 & $\mathrm{C}$ & 0.009 & 0.009 & 0.7 & 1.06 & $<\mathrm{dl}$ & 20 \\
\hline S04 & B & 0.083 & 0.103 & 6.7 & 1.24 & 0.001 & 484 \\
\hline S05 & B & 0.384 & 0.436 & 31.1 & 1.14 & 0.106 & 1,178 \\
\hline S06 & B & 0.104 & 0.183 & 8.4 & 1.77 & 0.019 & 376 \\
\hline S07 & B & 0.046 & 0.046 & 3.8 & 1.00 & 0.003 & 111 \\
\hline S08 & B & 0.032 & 0.030 & 2.6 & 0.95 & 0.020 & 26 \\
\hline S09 & B & 0.007 & 0.007 & 0.6 & 1.03 & $<\mathrm{dl}$ & 154 \\
\hline S10 & B & 0.009 & 0.008 & 0.7 & 0.89 & $<\mathrm{dl}$ & 311 \\
\hline S11 & B & 0.025 & 0.025 & 2.0 & 1.00 & 0.001 & 599 \\
\hline $\mathrm{S} 12$ & B & 0.157 & 0.181 & 12.7 & 1.15 & 0.004 & 1,609 \\
\hline $\mathrm{S} 13$ & B & 0.069 & 0.087 & 5.6 & 1.26 & 0.007 & 60 \\
\hline Mean & & 0.087 & 0.094 & 6.6 & 1.05 & 0.027 & 694 \\
\hline Median & & 0.043 & 0.044 & 3.3 & 1.03 & 0.016 & 344 \\
\hline SD & & 0.13 & 0.13 & 10.1 & 0.18 & 0.04 & 890 \\
\hline $\mathrm{CV}$ & & 1.46 & 1.43 & 1.54 & 0.18 & 1.49 & 1.28 \\
\hline Minimum & & $<\mathrm{dl}$ & $<\mathrm{dl}$ & $<\mathrm{dl}$ & nd & $<\mathrm{dl}$ & 1.40 \\
\hline Maximum & & 0.679 & 0.680 & 55.0 & 1.77 & 0.234 & 3,856 \\
\hline$n$ & & 41 & 41 & 41 & 41 & 41 & 32 \\
\hline
\end{tabular}



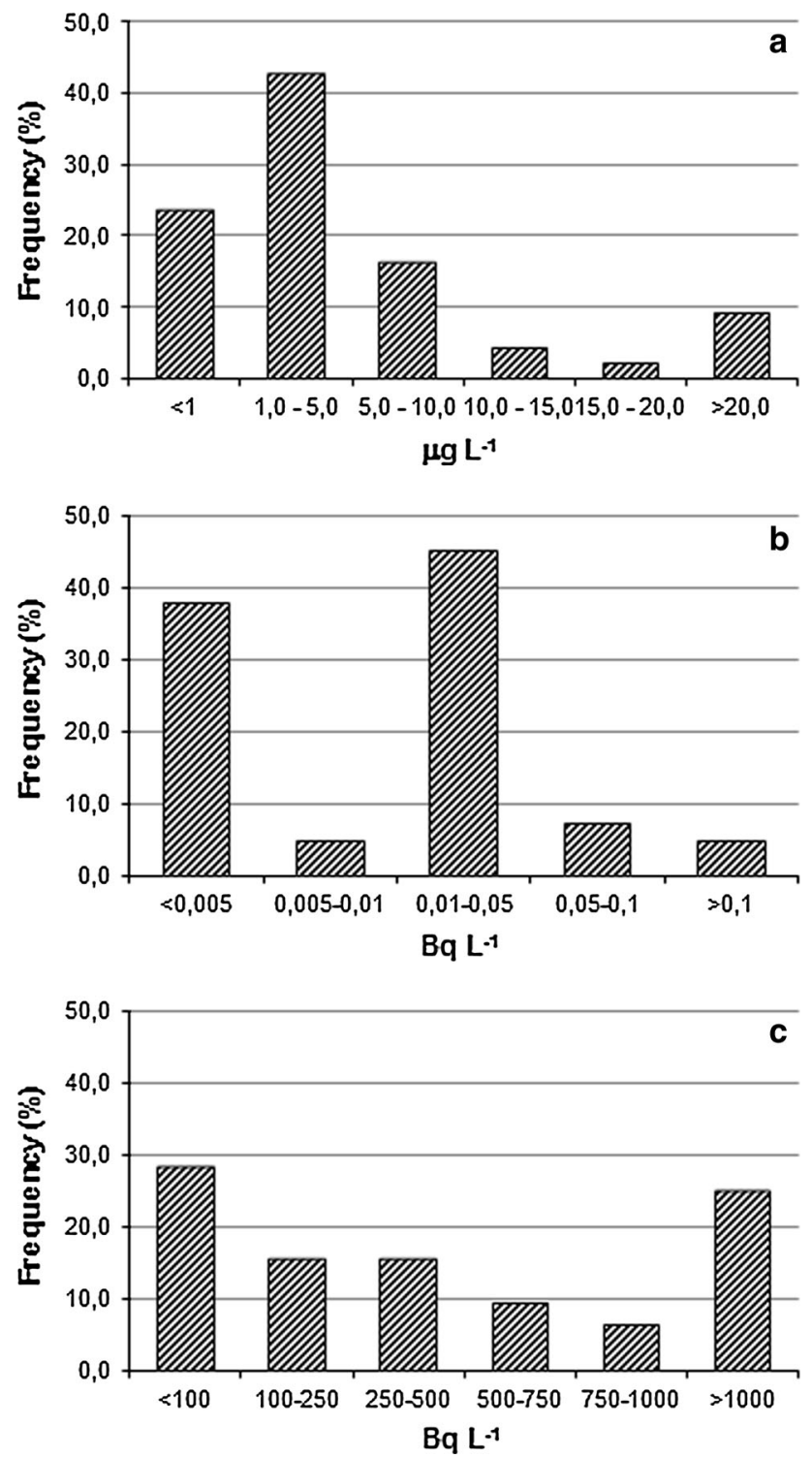

Fig. 2 Histograms of the distribution of the $U_{\text {natural }}$ (a) and the activity of the isotopes ${ }^{226} \mathrm{Ra}(\mathbf{b})$ and ${ }^{222} \mathrm{Rn}(\mathbf{c})$, measured in the water samples collected in the study area

values for each age group are plotted in Fig 3. The highest dose would be received by the youngest groups (babies and infants) in accordance with the activity-dose coefficients that are considerably higher for these age groups. The mean varies between $47.9 \mu \mathrm{Sv} /$ year(babies) and up to $11.6 \mu \mathrm{Sv} / \mathrm{year}$ (adults) and the median from $28.1 \mu \mathrm{Sv} / \mathrm{year}$ and up to $6.6 \mu \mathrm{Sv} / y e a r$, for the same groups. The maximum values calculated for the same age groups are 325.0 and $64.6 \mu \mathrm{Sv} / \mathrm{year}$, respectively. In $17 \%$ of the samples the total effective dose is higher than the action limit that is specified in the legislation (100 $\mu$ Sv/year, EU 1998, 2012; WHO 2011).These samples should consequently be classified as non-drinkable. A radiological study performed by Torres et al. (1992) in drinking water from the Ciudad
Rodrigo area also showed that some of the samples could not be considered safe for human use, as they were not in accordance with the terms set by the current legislation.

The high variability detected in both the radiological and non-radiological parameters that were measured in the water samples from both regions can be explained by the existing geological bedrock. Hercynian granitic rocks are dominant in Nisa, while on the Spanish side of the border, metasediments of the pre-Ordovician SGC are prevalent. In the latter region, the dataset also includes three water samples collected from the Tertiary sediments.

The results obtained in both areas are compared in Table 4 . This can be done by arranging the dataset on the basis of the geographic location of the samples and considering the median to be the preferable statistical parameter to describe the central tendency of the distribution. This seems preferable given the lognormal distribution of the dataset.

There is a clear acidic tendency in the granitic waters, whereas the metasedimentary groundwater is close to neutral. Because both the EC and the sum of the major cations are much higher in the water samples from Ciudad Rodrigo, a higher mineralization is expected in this area. A large number of the analyzed samples showed low to very low hardness (soft to moderately hard water), but the majority of the samples from Ciudad Rodrigo showed hardness values above $150 \mathrm{mg} \mathrm{L}^{-1} \mathrm{CaCO}_{3}$ (hard water) and sometimes above $300 \mathrm{mg} \mathrm{L}^{-1} \mathrm{CaCO}_{3}$ (very hard water).

In terms of major cations, there is a clear difference between the groundwaters of Nisa and Ciudad Rodrigo. While $\mathrm{Na}$ is the dominant cation in the granitic domain (Nisa), Ca largely prevails in the metasedimentary terrains of Ciudad Rodrigo. Moreover, the Mg concentrations are quite close to the $\mathrm{Na}$ values in this particular setting. The projection of major cations in a Piper diagram (Fig. 4) highlights the hydrogeochemical differences between the two studied zones: the Nisa groundwater samples are plotted on the $\mathrm{Na}-\mathrm{K}$ facies, while the groundwater samples from Ciudad Rodrigo are included on the $\mathrm{Ca}-\mathrm{Mg}$ facies. Higher $\mathrm{SiO}_{2}$ concentrations occur on groundwater samples from Nisa, as was to be expected in view of the dominance of granitic rocks in this area.

With regard to minor constituents, the higher values of $\mathrm{Al}, \mathrm{Mn}$ and $\mathrm{Zn}$ in the Nisa groundwater should be noted; the highest values are observed in the water samples from metasediments. The Ciudad Rodrigo groundwater samples show higher concentrations of $\mathrm{Ba}$.

In spite of the lack of major anion $\left(\mathrm{HCO}_{3}{ }^{-}, \mathrm{Cl}^{-}\right.$and $\mathrm{SO}_{4}{ }^{2-}$ ) analysis, the lower cation concentrations obtained in the groundwater samples of the Nisa zone point to the presence of a "granitic water" with a shallow subterranean circulation and a short residence period. However, the high 
Table 3 Effective dose from exposure to ionizing radiation (in $\mu \mathrm{Sv} /$ year) through the consumption of groundwater collected in the shallow aquifers of Nisa and Ciudad Rodrigo areas

\begin{tabular}{lcrrrc}
\hline Statistical parameter & \multicolumn{6}{l}{ Age groups (years) } \\
\cline { 2 - 6 } & $<1$ & \multicolumn{1}{c}{$1-2$} & $2-7$ & $7-10$ & $>17$ \\
\hline Mean & 47.9 & 17.2 & 11.3 & 12.3 & 11.6 \\
Median & 28.1 & 9.8 & 6.4 & 7.2 & 6.6 \\
SD & 62.6 & 22.0 & 14.5 & 15.9 & 14.4 \\
$\mathrm{CV}$ & 1.31 & 1.28 & 1.28 & 1.30 & 1.25 \\
Minimum & 0.002 & 0.001 & 0.001 & 0.001 & 0.001 \\
Maximum & 325.0 & 104.2 & 67.9 & 80.9 & 64.6 \\
\hline
\end{tabular}

The effective dose was calculated for different age groups of the population following the methodology described in Desideri et al. (2007)

$S D$ standard deviation $(1 \sigma), C V$ coefficient of variation

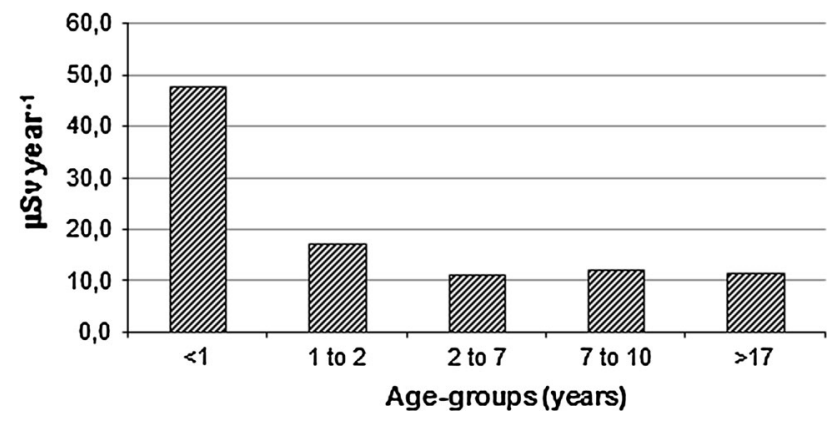

Fig. 3 Effective dose (mean value) for different age groups of the population of the studied areas from exposure to ionizing radiation through water consumption. Data from Table 3

content in minor constituents in the metasediments of the thermal aureole suggests that this could be related to rock mineralization in metallic oxides and sulfides. The hydrogeochemistry of groundwater samples collected in the Spanish area indicates higher water mineralization and specific enrichment in $\mathrm{Ca}$ and $\mathrm{Mg}$. In contrast to the high levels of these minerals, it shows a slight depletion in $\mathrm{SiO}_{2}$. These characteristics are unmistakably associated with the frequent occurrence of carbonate levels and black shales within the metasedimentary terrains (Arribas et al. 1983).

Despite the general hydrogeochemical trends explained above, the results show important physicochemical spatial variability, both in the Nisa and Ciudad Rodrigo groundwater samples. This hydrogeochemical heterogeneity is associated with specific attributes (both mineralogical and structural) of the setting of each groundwater sample (spring, dug-well or borehole). This setting limits the circulation and residence period of groundwater, as well as the interaction between rockwater in the aquifer.
Table 4 Median, minimum and maximum values calculated from the physical and chemical data obtained from water samples from the studied areas

\begin{tabular}{lll}
\hline Parameter & Nisa & Ciudad Rodrigo \\
\hline $\mathrm{pH}$ & $5.60(5.20-7.30)$ & $6.72(6.37-7.50)$ \\
$\mathrm{EC}\left(\mu \mathrm{S} \mathrm{cm}^{-1}\right)$ & $150(70-694)$ & $624(294-1,058)$ \\
$\mathrm{Na}\left(\mathrm{mg} \mathrm{L}^{-1}\right)$ & $12.07(8.36-46.76)$ & $20.30(7.60-49.63)$ \\
$\mathrm{Mg}\left(\mathrm{mg} \mathrm{L}^{-1}\right)$ & $1.67(0.43-20.42)$ & $18.49(3.20-34.63)$ \\
$\mathrm{Ca}\left(\mathrm{mg} \mathrm{L}^{-1}\right)$ & $3.51(0.55-21.69)$ & $40.51(17.0-118.82)$ \\
$\mathrm{K}\left(\mathrm{mg} \mathrm{L}^{-1}\right)$ & $0.98(0.36-9.0)$ & $1.90(0.48-11.96)$ \\
$\mathrm{Hardness}$ & $16.05(4.54-139.18)$ & $187.24(77.67-425.92)$ \\
$\left(\mathrm{mg} \mathrm{L}^{-1} \mathrm{CaCO}_{3}\right)$ & & \\
$\mathrm{SiO}\left(\mathrm{mg} \mathrm{L}^{-1}\right)$ & $6.80(3.44-12.61)$ & $6.02(4.42-7.73)$ \\
$\mathrm{Fe}\left(\mathrm{mg} \mathrm{L}^{-1}\right)$ & $0.034(<\mathrm{dl}-0.181)$ & $0.009(<\mathrm{dl}-0.188)$ \\
$\mathrm{Al}\left(\mathrm{mg} \mathrm{L}^{-1}\right)$ & $0.017(<\mathrm{dl}-0.090)$ & $0.009(0.003-0.036)$ \\
$\mathrm{Mn}\left(\mathrm{mg} \mathrm{L}^{-1}\right)$ & $0.006(<\mathrm{dl}-0.218)$ & $0.001(<\mathrm{dl}-0.003)$ \\
$\mathrm{Ni}\left(\mathrm{mg} \mathrm{L}^{-1}\right)$ & $0.008(<\mathrm{dl}-0.015)$ & $0.001(<\mathrm{dl}-0.001)$ \\
$\mathrm{Zn}\left(\mathrm{mg} \mathrm{L}^{-1}\right)$ & $0.027(<\mathrm{dl}-0.043)$ & $0.006(0.005-0.008)$ \\
$\mathrm{As}\left(\mathrm{mg} \mathrm{L}^{-1}\right)$ & $0.006(<\mathrm{dl}-0.012)$ & $0.003(<\mathrm{dl}-0.026)$ \\
$\mathrm{Ba}\left(\mathrm{mg} \mathrm{L}^{-1}\right)$ & $0.009(0.001-0.035)$ & $0.021(0.005-0.061)$ \\
\hline
\end{tabular}

Overall, the values of $\mathrm{pH}, \mathrm{EC}$, major cations and $\mathrm{Fe}$ obtained in this study are consistent with the mean values obtained for groundwater associated with granites and metasediments of the Central Portugal region (Almeida et al. 2000).

An analysis similar to the radiological data can be performed, since it is also expected that lithology should be the main source of variation of the activities of the analyzed radioisotopes. In this case, a slightly different approach to interpret the data was attempted because the radiological dataset has a larger number of samples associated with the metasediments in the Nisa region (16 against 2 in the previous one). Water samples were rearranged on account of the described rock types and subsequently the statistical parameters were calculated for each group. The results can then be graphically outlined as a box and whisker projection as shown in Fig. 5 for $U_{\text {natural }}$, ${ }^{238} \mathrm{U} /{ }^{234} \mathrm{U},{ }^{226} \mathrm{Ra}$ and ${ }^{222} \mathrm{Rn}$. Additional statistical parameters have been calculated and listed for each lithology in Table 5.

The sediments from the Tertiary cover transfer only minor amounts of radioisotopes to the groundwater; for instance, the median of the activities of ${ }^{226} \mathrm{Ra}$ and ${ }^{222} \mathrm{Rn}$ is only $0.001 \mathrm{~Bq} \mathrm{~L}^{-1}$ and $20 \mathrm{~Bq} \mathrm{~L}^{-1}$, respectively.

The uranium isotopes have similar activities in water associated with both granites and metasediments, but the variability is higher in this last lithology. The median of the activity in ${ }^{234} \mathrm{U}$ is $0.041 \mathrm{~Bq} \mathrm{~L}^{-1}$ and $0.046 \mathrm{~Bq} \mathrm{~L}^{-1}$ and in ${ }^{238} \mathrm{U}$ is $0.042 \mathrm{~Bq} \mathrm{~L}^{-1}$ and $0.044 \mathrm{~Bq} \mathrm{~L}^{-1}$, respectively, for granites and metasediments. $\mathrm{U}_{\text {natural }}$ shows a similar trend, 
Fig. 4 Projection in Piper diagram of major cations (meq $\mathrm{L}^{-1}$ ) of groundwater samples from the two studied areas (Nisa and Ciudad Rodrigo); data from Table 4

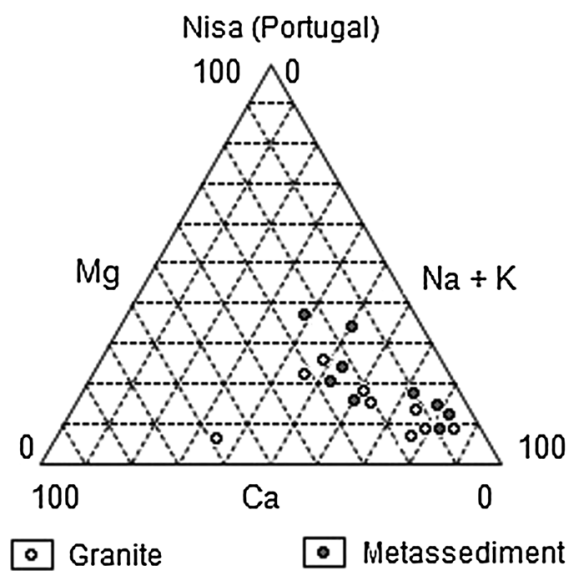

Ciudad Rodrigo (Spain)

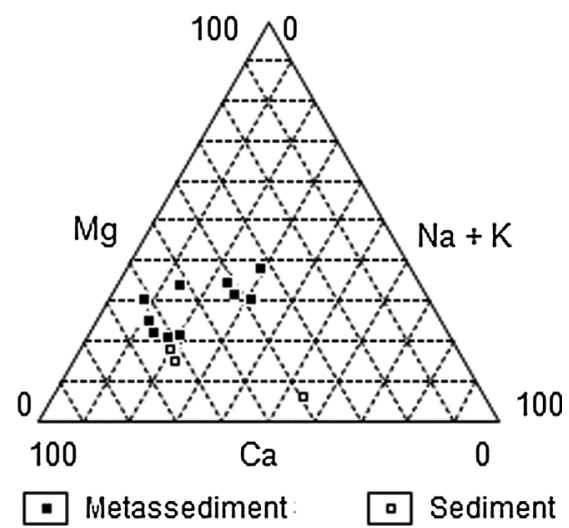

as expected, with the median slightly ranging from $3.3 \mu \mathrm{g} \mathrm{L}^{-1}$ in granites to $3.8 \mu \mathrm{g} \mathrm{L}^{-1}$ in metasediments. The ${ }^{234} \mathrm{U} /{ }^{238} \mathrm{U}$ ratio is marginally higher in the water from the latter rock type, but higher than 1.0 in both cases.

Groundwater circulating in granites is highly enriched in ${ }^{226} \mathrm{Ra}$ and ${ }^{222} \mathrm{Rn}$ when compared with samples collected from metasediments. For the first isotope, a median of $0.030 \mathrm{~Bq} \mathrm{~L}^{-1}$ was measured in granites and $0.019 \mathrm{~Bq} \mathrm{~L}^{-1}$ in metasediments; the median for radon gas was 532 and $311 \mathrm{~Bq} \mathrm{~L}^{-1}$, respectively, for the same rock types. The occurrence of outliers, projected in Fig. 5, is a common situation that has been previously observed in similar geological settings (Andrews et al. 1989; Salonen 1994; Salim et al. 2002; Vinson et al. 2009), not only for groundwater but also for samples taken from other environmental compartments. The outliers are often linked, on a local scale, to the occurrence of rocks highly enriched in uranium, which allows the transfer of the radioisotopes formed in its decay chain to the circulating waters, as shown by Pereira et al. (2010); Pereira and Neves (2012). Therefore, the same interpretation is made in the present study concerning the meaning of the outliers.

The results regarding the radiological data in groundwater samples are in agreement with others already known in areas that show a similar geological setting and a high radiation natural background as their distinctive characteristic. For instance, in the Oliveira do Hospital region (Central Portugal), which is also located in the uranium metalogenetic province, several studies have been carried out in the last few years to evaluate the distribution of the radioisotopes of the uranium decay chain in groundwater (e.g., Pereira et al. 2010; Pinto et al. 2008). In water samples collected mainly in Hercynian granites, the median estimated for $\mathrm{U}_{\text {natural }}$ was $1.6 \mu \mathrm{g} \mathrm{L}^{-1}$ with a maximum of $29.9 \mu \mathrm{g} \mathrm{L}^{-1}$, and $0.06 \mathrm{~Bq} \mathrm{~L}^{-1}$ for ${ }^{226} \mathrm{Ra}$ with a maximum of $1.54 \mathrm{~Bq} \mathrm{~L}^{-1}$. For radon gas the median was $514 \mathrm{~Bq} \mathrm{~L}^{-1}$ with a maximum of $5,416 \mathrm{~Bq} \mathrm{~L}^{-1}$. In the area surrounding the old uranium mine of Los Ratones
(Cáceres, Spain), Gomez et al. (2006) found uranium concentrations in groundwater that fluctuated between $<1 \mu \mathrm{g} \mathrm{L}^{-1}$ and $104 \mu \mathrm{g} \mathrm{L}^{-1}$. Similar findings are referred to in Soto et al. (1995), Sáinz et al. (2007)and CSN (2007).

However, the radiological signature of groundwater circulating in areas with similar geological settings and lithology changes dramatically when no high natural radiation background is present. For instance, in the Sabugal region (located in Central Portugal, North of Nisa), Almeida (2012) indicates a median of $0.9 \mu \mathrm{g} \mathrm{L}^{-1}$ with a maximum of $2.1 \mathrm{~g} \mathrm{~L} \mathrm{~L}^{-1}$ for $\mathrm{U}_{\text {natural }}, 0.001 \mathrm{~Bq} \mathrm{~L}^{-1}$ for ${ }^{226} \mathrm{Ra}$, with a maximum of $0.025 \mathrm{~Bq} \mathrm{~L}^{-1}$, and $162 \mathrm{~Bq} \mathrm{~L}^{-1}$ for radon gas with a maximum of $1,601 \mathrm{~Bq} \mathrm{~L}^{-1}$. In the Castelo Branco region, a sample set of 25 samples provided the following results: $U_{\text {natural }}$ varying between $<0.1$ to $5.1 \mu \mathrm{g} \mathrm{L}^{-1}$, with most of the samples with ${ }^{226} \mathrm{Ra}$ activity under the detection limit of $0.005 \mathrm{~Bq} \mathrm{~L}^{-1}$, and radon gas with a median of $26 \mathrm{~Bq} \mathrm{~L}^{-1}$ and a maximum of $130 \mathrm{~Bq} \mathrm{~L}^{-1}$ (unpublished data from the authors).

In addition to the presence of the uranium-enriched rocks, other factors could be involved in the water-rock interaction. Such factors can favor or hamper the transfer of the radioisotopes to the water. To test this hypothesis, a comparison was performed between samples from both sides of the border, but collected in the same lithological unit (the pre-Ordovician metasedimentary rocks-SGC) taking only into consideration the available data (uranium and radium isotopes; Fig. 6). With regard to uranium, the variance is similar but the median is higher in Ciudad Rodrigo. The samples from this area also display a higher ${ }^{234} \mathrm{U} /{ }^{238} \mathrm{U}$ ratio compared with samples from Nisa. However, the latter show enrichment in ${ }^{226} \mathrm{Ra}$ in comparison to the water samples of the same geological unit, but located on the Spanish side of the border.

The observed differences can be explained by the typology of the uranium mineralization and/or in the presence of other chemical elements in water composition. 
Fig. 5 Box and whisker plots of the radiological data obtained from groundwater samples of the studied areas according to lithology. SGC-metasediments of the Schist and Graywacke Complex. Maximum values are indicated as outliers

Table 5 Basic statistical parameters estimated from the radiological data obtained from all the groundwater samples collected at points located in Hercynian granites outcropping in the Portuguese side (A), in rocks from the SGC outcropping on both sides of the Spanish-Portuguese border (B) and in Tertiary sediments outcropping on the Spanish side (C)

$S D$ standard deviation $(1 \sigma), C V$ coefficient of variation, $<d l$ lower than the detection limit, $n$ the number of samples
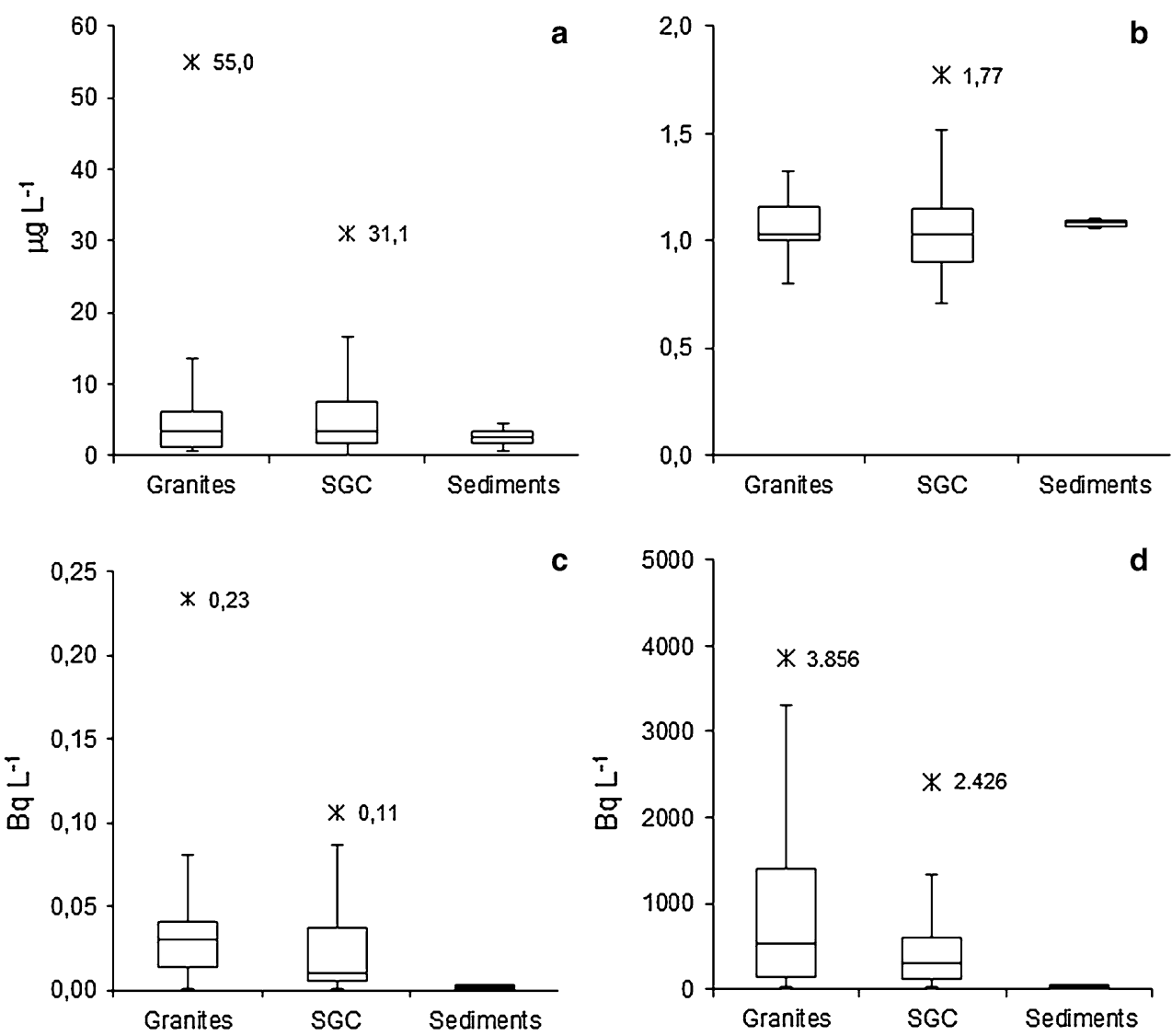

\begin{tabular}{|c|c|c|c|c|c|c|c|}
\hline Parameter & Lithology & $\begin{array}{l}\left.{ }^{238} \mathrm{U}^{-1}\right) \\
\left(\mathrm{Bq} \mathrm{L}^{-1}\right)\end{array}$ & $\begin{array}{l}\left.{ }^{234} \mathrm{U}^{-1}\right) \\
\left(\mathrm{Bq} \mathrm{L}^{-1}\right)\end{array}$ & $\begin{array}{l}\mathrm{U}_{\text {natural }} \\
\left(\mu \mathrm{g} \mathrm{L}^{-1}\right)\end{array}$ & ${ }^{234} U^{238} U$ & $\begin{array}{l}{ }^{226} \mathrm{Ra} \\
\left(\mathrm{Bq} \mathrm{L}{ }^{-1}\right)\end{array}$ & $\begin{array}{l}{ }^{222} \mathrm{Rn} \\
\left(\mathrm{Bq} \mathrm{L}^{-1}\right)\end{array}$ \\
\hline \multirow[t]{3}{*}{ Mean } & A & 0.092 & 0.098 & 7.4 & 1.05 & 0.041 & 914 \\
\hline & B & 0.089 & 0.097 & 7.2 & 1.05 & 0.026 & 580 \\
\hline & $\mathrm{C}$ & 0.032 & 0.035 & 2.6 & 1.08 & 0.001 & 16 \\
\hline \multirow[t]{3}{*}{ Median } & A & 0.041 & 0.042 & 3.3 & 1.03 & 0.030 & 532 \\
\hline & B & 0.046 & 0.044 & 3.8 & 1.03 & 0.019 & 311 \\
\hline & $\mathrm{C}$ & 0.032 & 0.035 & 2.6 & 1.08 & 0.001 & 20 \\
\hline \multirow[t]{3}{*}{ SD } & A & 0.17 & 0.17 & 13.4 & 0.14 & 0.06 & 1,028 \\
\hline & B & 0.10 & 0.11 & 8.2 & 0.22 & 0.03 & 729 \\
\hline & $\mathrm{C}$ & 0.03 & 0.04 & 2.6 & 0.03 & 0.00 & 13 \\
\hline \multirow[t]{3}{*}{$\mathrm{CV}$} & A & 1.80 & 1.72 & 1.80 & 0.14 & 1.38 & 1.13 \\
\hline & B & 1.13 & 1.16 & 1.13 & 0.21 & 1.06 & 1.26 \\
\hline & $\mathrm{C}$ & 1.03 & 1.05 & 1.03 & 0.03 & 0.31 & 0.81 \\
\hline \multirow[t]{3}{*}{ Minimum } & A & 0.007 & 0.007 & 0.57 & 0.80 & 0.001 & 17 \\
\hline & B & $<\mathrm{dl}$ & $<\mathrm{dl}$ & $<\mathrm{dl}$ & 0.71 & $<\mathrm{dl}$ & 26 \\
\hline & $\mathrm{C}$ & $<\mathrm{dl}$ & $<\mathrm{dl}$ & $<\mathrm{dl}$ & 1.06 & $<\mathrm{dl}$ & 1 \\
\hline \multirow[t]{3}{*}{ Maximum } & A & 0.679 & 0.680 & 55.0 & 1.33 & 0.234 & 3,856 \\
\hline & B & 0.384 & 0.436 & 31.1 & 1.77 & 0.106 & 2,426 \\
\hline & $\mathrm{C}$ & 0.05 & 0.06 & 4.4 & 1.11 & 0.002 & 26 \\
\hline \multirow[t]{3}{*}{$n$} & A & 15 & 15 & 15 & 15 & 15 & 15 \\
\hline & B & 23 & 23 & 23 & 23 & 23 & 13 \\
\hline & $\mathrm{C}$ & 3 & 3 & 3 & 3 & 3 & 3 \\
\hline
\end{tabular}



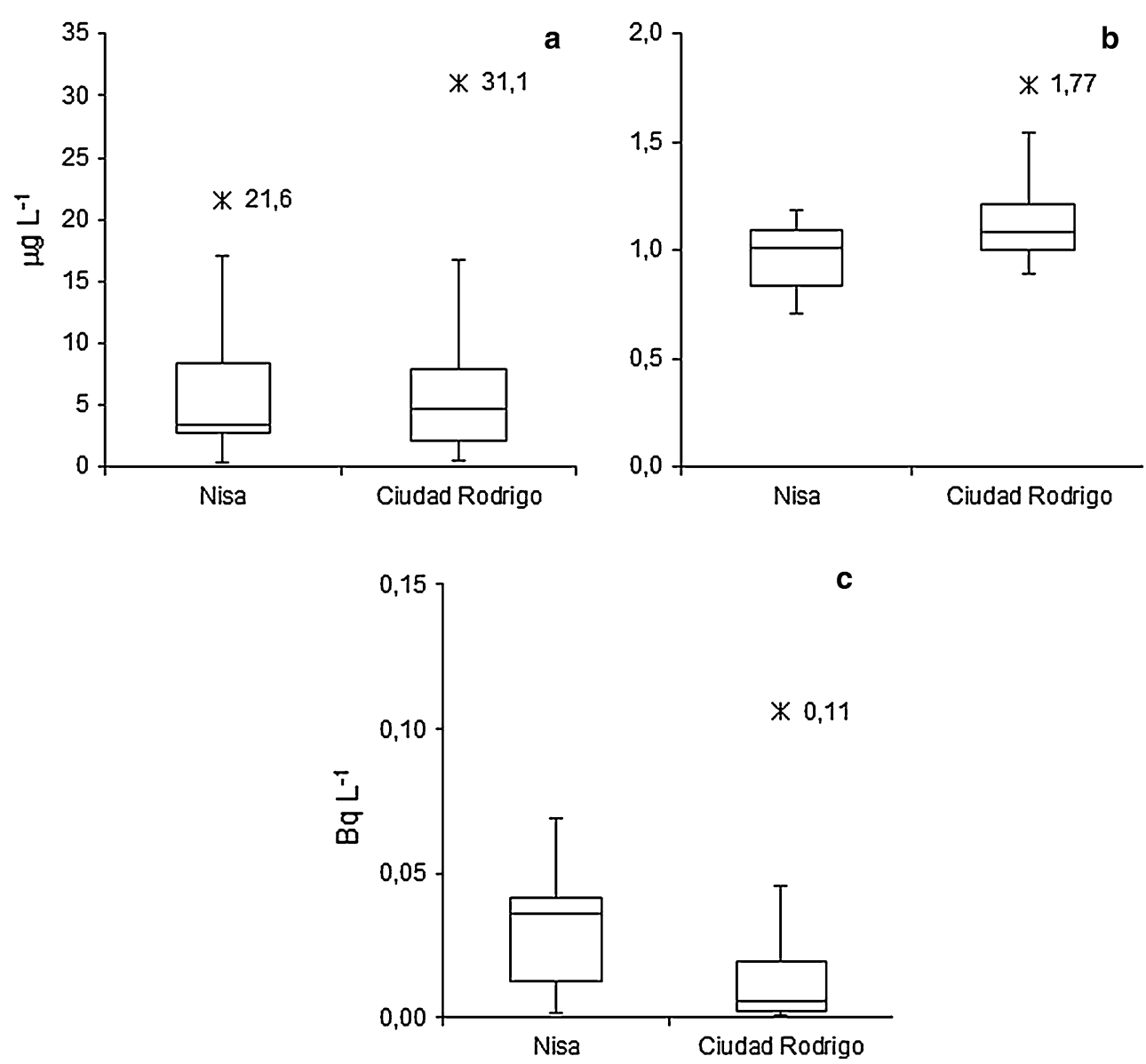

Fig. 6 Box and whisker plots of the radiological data obtained from groundwater samples of the studied areas according to geography. Maximum values are indicated as outliers

The high $\mathrm{pH}$ and the enrichment in $\mathrm{Ca}-\mathrm{Mg}$ in the groundwater of the Ciudad Rodrigo area may be responsible for increasing the transfer of the isotopes of $U$ (with emphasis in ${ }^{234} \mathrm{U}$ ) from the rock to the water. The oxidizing conditions associated with the shallow aquifers and the presence of carbonates may enhance the solubility of uranium in water (Scalan 1977, which can in turn explain why the highest uranium activity is on the Spanish side. The difference in behavior of the water-rock interaction of the ${ }^{234} \mathrm{U}$ isotope compared to that of ${ }^{238} \mathrm{U}$ has been observed in similar settings (Åkerblom 1994).

The typology of the uranium mineralization in the Nisa region promotes, on the other hand, the highest transfer rate for radium. This typology is of a supergene type, solely composed of secondary uranium minerals such as autunite (Dias and Andrade 1970; Neiva and Dias 2010). This finding seems contradictory to previous studies that showed a correlation between ${ }^{226} \mathrm{Ra}$ activity and $\mathrm{Ca}$ or Ba content in the groundwater. These elements are enriched in water associated with the metasediments of Ciudad Rodrigo (e.g., Sturchio et al. 2001). The majority of the Portuguese samples were collected from metasediments, which are highly enriched in supergene uranium minerals, suggesting that most of the radium becomes part of the water composition preferentially by desorption from aquifer surfaces, alpha-recoil from the disintegration of ${ }^{230} \mathrm{Th}$ occurring as coatings on the same surfaces or leaching from radiationdamaged crystals (Dickson 1990; Krishnaswami et al. 1982; Ku et al. 1992).

The differences in the activities of the radioisotopes measured in groundwater samples from both sides of the border imply that the radiological risk associated with the exploitation of the aquifers of the studied regions for human consumption would not be the same for both regions. The methodology followed in this work has taken into account its geographical location and the results for the aforementioned age groups, as defined in EU (1998), and projected in Fig. 7 (median values). At every instance, the effective dose is higher in the aquifer of the Nisa region. This can be explained by the higher activities, on average, observed in the samples from that region, in particular that of ${ }^{226} \mathrm{Ra}$. 


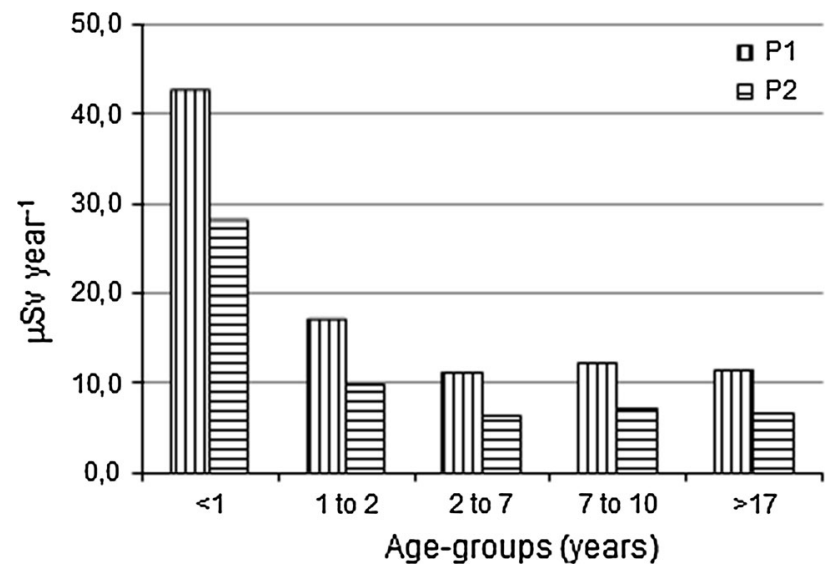

Fig. 7 Mean of the calculated effective dose for different age groups of the population of Nisa $(P 1)$ and Ciudad Rodrigo $(P 2)$ regions from exposure to ionizing radiation through water consumption

It should be emphasized that uranium exploitation has never been carried out on a large scale in the past in the Nisa region; only small works were performed for prospection and resource evaluation (Dias et al. 1990). On the Spanish side, on the contrary, the uranium exploitation occurred on a commercial scale. However, the present radiological risk in the groundwater seems to be higher on the Portuguese side, which highlights the influence of natural background in human health, an observation that is in line with other results obtained from Iberia or elsewhere (e.g., Pereira and Neves 2012; Turtiainen and Kostiainen 2013).

\section{Conclusions}

The present hydrochemical and radiological study was carried out in groundwater samples collected in two areas of similar geological setting and located on both sides of the Portuguese and Spanish border. These areas are characterized by a common high natural radiation background, but differ in terms of past uranium exploitation activity, which is only significant on the Spanish side.

From the physical, chemical and radiological data, it can be concluded that the two areas show specific signatures as a result of their lithology, mostly of granitic composition on the Portuguese side and metasedimentary (schists and graywackes) on the Spanish sector. However, the radiological signature of the groundwater associated with metasedimentary rocks on both areas was also found to be distinct. While the activity of uranium isotopes is higher on the Spanish side, radium isotopes have the opposite behavior; their activities are higher on the Portuguese side.

Major and trace element contents in both areas display a range of variation similar to the one already recognized in groundwater from similar lithologies, but with a much lower natural radiation background. However, the radioisotope activities in the groundwater from low radiation background areas are much lower than those observed in the studied regions, with a bedrock composition of the same rock types but with a higher radiation background. Thus, these results point to a lack of correlation between the physical and chemical parameters of the waters and their radioisotope contents. Past studies have provided insight as to how radioisotope activity can be estimated from chemical data, but the results obtained in the present study raise questions as to whether or not there is such a relationship, at least in what pertains to the water's cationic content (Andrews et al. 1989; Dickson 1990; Krishnaswami et al. 1991; Sturchio et al. 2001). On the contrary, lithological control and ore typology seem to be the most important factors in determining the chemical and radiological properties of the rocks.

The health risk associated with the consumption of the groundwater collected in the shallow aquifers of the studied areas was evaluated mainly from the estimation of the effective dose from exposure to ionizing radiation. The risk is lower on the Spanish side in spite of this area having been subjected to large-scale exploitation works for uranium mining, while these works were limited to small prospection activities on the Portuguese side. This finding reinforces the importance of the natural background as the most effective method of assessing the ionizing radiation by the human population.

Acknowledgments Project SA11/0A09 (Junta de Castilla y León) funded part of the analytical work for this research. Paulo Pinto is thanked for his contribution in sampling and in the radiological analysis of the waters. We thank an anonymous reviewer for providing suggestions that considerably improved the final version of the manuscript.

\section{References}

Åkerblom G (1994) Ground radon-monitoring procedures in Sweden. Geoscientist 4:21-27

Almeida RMP (2012) Sources and drinkable-water distribution network in Sabugal area. Dissertation, Universidade da Beira Interior (in Portuguese)

Almeida C, Mendonça JL, Jesus MR, Gomes AJ (2000) Groundwater systems in continental Portugal. Lisboa, Centro de Geologia/ Instituto da Água (in Portuguese)

Andrews N, Ford DJ, Hussain N, Trivedi D, Youngman MJ (1989) Natural radioelement solution by circulating groundwater in the Stripa granite. Geoch et Cosmochim Acta 53(8):1791-1802

Arribas A (1985) Source, transport and deposition of uranium in the ore deposits of schists from the Salamanca Province. Estud Geol 41:301-321 (in Spanish)

Arribas A, Martín Izard A, Montes J (1983) U mineralizations in Alameda de Gardón and relation with the geotectonic and metallogenic setting of the schists from west of Salamanca. Stud Geol Salmant 18:201-224 (in Spanish) 
Berkeley Resources (2013). http://www.berkeleyresources.com.au/ projects-overview/. Accessed 18 Nov 2013

Campos ABA (2002) Radiological impacts associated to Uranium Ores: the case of Nisa ore (Central Portugal). Dissertation, University of Coimbra (in Portuguese)

Carvalho FP, Oliveira JM, Malta M (2009) Analyses of radionuclides in soil, water and agriculture products near the Urgeiriça uranium mine in Portugal. J Radioanal Nucl Chem 281:479-484

CSN (2007)-Remediation techniques applied to radioactive contaminated water for human consumption. Consejo de Seguridad Nacional, Colección Informes técnicos, 18 (in Spanish)

Davis SN, DeWiest RJM (1967) Hydrogeology, 2nd edn edn. Willey, New York

Desideri D, Meli MA, Feduzi L, Roselli C, Rongoni A, Saetta D (2007) ${ }^{238} \mathrm{U},{ }^{234} \mathrm{U},{ }^{226} \mathrm{Ra},{ }^{210}$ Po concentrations of bottled mineral waters in Italy and their dose contribution. J Environ Rad 94:86-97

Neiva JMC, Dias, JMM (2010) Mineralization and genesis of Portuguese uranium deposits. In: Neiva JMC, Ribeiro A, Victor M., Noronha F., Ramalho M. (eds) Ciências Geológicas: Ensino, Investigação e sua História. vol II:109-119 (in Portuguese)

Dias JMM, Andrade AAS (1970) Portuguese uranium deposits. Memórias e Notícias. Publ Mus Lab Mineral Geol Univ. Coimbra 70:1-22

Dias JMM, Marques JC, Ponte MB, Campos ABA (1990) Uranium in Azere and Nisa areas (Portugal). In: Gummiel P, Guezala J, Dias JMM, Arribas A (eds) Development of new multidisciplinary techniques for mineral exploration in several areas of the western Iberian Península, vol 2, pp 162-198

Dickson BL (1990) Radium in groundwater. The environmental behavior of radium, vol 1. Intl Atomic Energy Agency, Viena, pp 335-372

EU (1998) Council Directive 98/83/EC of 3 November 1998 on the quality of water intended for water consumption. Off $\mathrm{J}$ Eur Union L 330, 05/12/98

EU (2001) European Commission Recommendation 2001/928/EURATOM. Off J Eur Commun L. 344, 28-12-2001

EU (2012) Proposal for a Council Directive laying down requirements for the protection of the health of the general public with regard to radioactive substances in water intended for human consumption. COM (2012) 147 final, 2012/0074 (NLE). Available from: http://eur-lex.europa.eu/LexUriServ/LexUriServ

Forte, M, Rosella R, Di Caprio, E, Bellinzona, S and Sgorbati, G (2002) Natural radionuclides measurements in drinking water by liquid scintillation counting. methods and results, In: 9th international symposium on environmental radiochemical analysis (Proc. Symp. Maidstone, Kent), p 15

Forte M, Rusconi R, Cazzaniga MT, Sgorbati G (2007) The measurement of radioactivity in Italian drinking waters. Microchemical J 85((1):98-102

Gómez P, Garralón A, Buil B, Turrero MJ, Sánchez L, Cruz B (2006) Modeling of geochemical processes related to uranium mobilization in the groundwater of a uranium mine. Sci Total Environ 366:295-309

Gonçalves CVM, Pereira AJSC (2007) Radionuclides in groundwater of the Serra do Buçaco region (Portugal). Proc. XXXV Congress of International Association of Hydrogeologists, Lisbon, p 9

Krishnaswami S, Graustein WC, Turekian KK, Dowd JF (1982) Radium, thorium, and radioactive lead isotopes in ground waters: application to the in situ determination of adsorption rate constants and retardation factors. Water Res 18:1663-1675

Krishnaswami S, Bhushan R, Baskaran M (1991) Radium isotopes and ${ }^{222} \mathrm{Rn}$ in shallow brines, Kharaghoda (India). Chem Geol (Isotope Geosci) 87:125-136
Ku TL, Luo S, Hammond D, Leslie B (1992) Applications of decayseries disequilibria to water-rock interactions and geothermal systems. In: Ivanovich M, Harmon RS (eds) Uranium-series disequilibrium: applications to earth, marine, and environmental sciences, 2nd edn. Clarendon Press, Oxford, pp 631-668

Martin Izard A, Arribas A, Arias D, Ruiz J, Fernández FJ (2002) The Fe deposit, west-central Spain: tectonic-hydrothermal uranium mineralization associated with transpressional faulting of the Alpine age. The Can Mineral 40:1505-1520

Pereira AJSC, Neves LJPF, Dias JMM, Campos ABA, Barbosa SVT (2004b) Evaluation of the radiological hazards from uranium mining and milling wastes (Urgeiriça, Central Portugal). Proc. XI International Congress of the International Radiation Protection Association, $10 \mathrm{p}$

Pinto PGN, Pereira, AJSC, Vicente AMP, Duarte R, Azevedo D, Neves LJPF (2008) Evaluation of the natural radioactivity in groundwater from Castelo Branco and Oliveira do Hospital areas. Proc "Congresso Nacional de Protecção contra Radiações", Lisboa, p 4 (in Portuguese)

Pereira D, Alonso MDR (2000) Duality of cordierite granites related to melt-restite segregation in the Peña Negra Anatectic Complex, central Spain. The Can Mineral 38:1329-1346

Pereira AJSC, Neves LJPF (2012) Estimation of the radiological background and dose assessment in areas with naturally occurring uranium geochemical anomalies: a case study in the Iberian Massif (Central Portugal). J Environ Radioactivity 112:96-107

Pereira AJSC, Neves LJPF, Dias JMM, Barbosa SVT (2004a) Evaluation of radionuclide contamination in the vicinity of the Cunha Baixa and Quinta do Bispo old uranium mines (Central Portugal). Radioprotecção 2:103-117

Pereira AJSC, Godinho MM, Neves LJPF (2010) On the influence of faulting on small-scale soil-gas radon variability: a case study in the Iberian Uranium Province. J Environ Radioactivity 101:875-882

Sáinz C, Quindós LS, Fernández PL, Goméz J, Fuente I, Quindós L, Matarranz JL (2007) High background radiation areas: the case of Villar de la Yegua town. Radiat Prot Dosim 125:565-567

Salim IMM, Pettersson HBL, Lund E (2002) Uranium and thorium series radionuclides in drinking water from drilled bedrock wells: correlation with geology and bedrock radioactivity and dose estimation. Radiat. Prot Dosim 102(3):249-258

Salonen L (1993) A rapid method for monitoring of uranium and radium in drinking water. Sci Total Environ (130/131):23-35

Salonen L (1994) ${ }^{238} \mathrm{U}$ series radionuclides as a source of increased radioactivity in groundwater originating from Finnish bedrock. Future groundwater resources at risk, Proceedings of the Helsinki Conference, IAHS Publ 22:71-148

Salonen, L. and Hukkanen, H. (1999) Application of liquid scintillation and alphaspectrometric methods in the survey of uranium series radionuclides in drinking water. The 45 th conference on bioassay, analytical and environmental radiochemistry, 18-22 October, Gaithersburg

Scalan JP (1977) Equilibria in uranyl carbonate systems II. J Inorg Nucl Chem 39:635-639

Soto J, Fernández P, Quindós LS, Gómez-Arozamena J (1995) Radioactivity in Spanish spas. Sci Total Environ 162:187-192

Sturchio NC, Banner JL, Binz CM, Heraty LB, Musgrove M (2001) Radium geochemistry of ground waters in Paleozoic carbonate aquifers midcontinent USA. Applied Geochem 16:109-122

Torres JS, Rodriguez NDC, Navarro PLF, Arozamena JG, Velarde GD, Poncela L, Quindós LS (1992) Evaluation of water quality in an area with high radiation background. San High Pub 66:197-201 (in Spanish) 
Turtiainen T, Kostiainen E (2013) Radiological hazards in Finnish cereals: comparison of man-made and natural sources. Cereal Res Commun 41:366-375

Vinson DS, Vengosh A, Hirschfeld D, Dwyer GS (2009) Relationships between radium and radon occurrence and hydrochemistry in fresh groundwater from fractured crystalline rocks, North Carolina (USA). Chem Geol 260(3-4):159-171

WHO (2011) Guidelines for drinking water quality, 4th edn. World Health Organization, Geneva 